\title{
Role of chemotherapy alone or in combination with hyperthermia in the primary treatment of intraocular retinoblastoma: preliminary results
}

C Levy, F Doz, E Quintana, H Pacquement, J Michon, P Schlienger, P Validire, B Asselain, L Desjardins, J M Zucker

\begin{abstract}
Background-The efficacy of the etoposide-carboplatin combination in extraocular retinoblastoma is well known. This drug combination is therefore used in intraocular retinoblastoma, as primary reduction chemotherapy, before local treatment. The use of carboplatin in combination with diode laser hyperthermia as local treatment (thermochemotherapy) has been recently described as a conservative approach avoiding external beam radiotherapy in posterior pole tumours. Methods-All patients were reviewed, who were treated for retinoblastoma at the Institut Curie between June 1994 and October 1995, in whom treatment included either reduction chemotherapy or thermochemotherapy or both modalities successively. 23 patients presenting with unilateral (three) or bilateral (20) intraocular retinoblastoma received neoadjuvant chemotherapy consisting of two courses of etoposide $150 \mathrm{mg} / \mathrm{m}^{2} /$ day and carboplatin $200 \mathrm{mg} / \mathrm{m}^{2} /$ day for 3 days. 15 patients (17 eyes), eight of whom had already received neoadjuvant chemotherapy, were treated by thermochemotherapy.

Results-Neoadjuvant chemotherapy:
\end{abstract} overall, seven eyes in seven patients could be treated conservatively, avoiding external beam irradiation, with a median follow up of 14 months. Thermochemotherapy: external beam irradiation was avoided for 14 of the 17 eyes treated.

Conclusion-Integration of neoadjuvant chemotherapy and combined treatment with carboplatin and diode laser, into the therapeutic armamentarium for retinoblastoma allows use of more aggressive treatments such as enucleation and external beam radiation.

(Br f Ophthalmol 1998;82:1154-1158)

Anatomie-Pathologique

$P$ Validire

Service de

Biostatistique

B Asselain

Correspondence to:

Dr C Levy, Service

d'Ophtalmologie, Institut

Curie, 26 rue d'Ulm, 75248

Paris cedex 05, France.

Accepted for publication 11 March 1998 photocoagulation, iodine plaque irradiation), the usual reference treatment is external beam irradiation therapy, ${ }^{34}$ with its well known adverse effects:

- growth defect of the irradiated orbitotemporal region with cosmetic sequelae ${ }^{15}$

- ocular adverse effects likely to worsen the visual (cataract) or functional prognosis (dry eye, photophobia) $)^{25-7}$

- rare endocrine adverse effects due to pituitary irradiation, mainly consisting of defective growth hormone or thyrotropin production $^{8}$

- most importantly, in the context of patients suffering from hereditary retinoblastoma (bilateral or multifocal unilateral), a greatly increased risk of sarcoma occurring within the irradiation field. ${ }^{5}{ }^{110}$

The development of alternative therapeutic strategies is therefore justified in order to avoid late effects of external beam radiotherapy.

Neoadjuvant chemotherapy in retinoblastoma with intraocular involvement can therefore be proposed in different clinical situations:

- in less extensive tumours, reduction of the tumour volume by chemotherapy can improve the accessibility to classic local conservative ophthalmological treatments or new modalities such as thermochemotherapy

- in more extensive tumours, chemotherapy may improve the accessibility to external irradiation as well as a better visual prognosis

The choice of the combination of etoposide and carboplatin for neoadjuvant chemotherapy of intraocular retinoblastoma is justified by the recognised activity of this combination in extraocular retinoblastoma, ${ }^{11-13}$ but also by other experiences in intraocular retinoblastoma. ${ }^{14-17}$

The toxic effect of hyperthermia and potentiation of this effect by simultaneous administration of platinum analogues have been demonstrated. ${ }^{18}{ }^{19}$ Intraocular retinoblastoma represents an interesting model for such treatment because hyperthermia can be delivered very precisely by using the diode laser. The first results of combined carboplatin and diode laser in retinoblastoma are very encouraging $^{2021}$ and suggest inclusion of this treatment in the armamentarium against retinoblastoma.

The essential indications for treatment by carboplatin and diode laser are small to medium size tumours posterior to the equator.

The objectives of our study were to evaluate the efficacy and toxicity of the combination of 
Table 1 Neoadjuvant chemotherapy

\begin{tabular}{|c|c|c|c|c|c|c|c|}
\hline Eye & & $\begin{array}{l}\text { Age at } \\
\text { diagnosis }\end{array}$ & $\begin{array}{l}\text { Reese group and } \\
\text { characteristics of the eyes at } \\
\text { diagnosis }\end{array}$ & Response to etoposide/carboplatin & $\begin{array}{l}\text { Treatment after } \\
\text { chemotherapy }\end{array}$ & $\begin{array}{l}\text { Relapse (initial time after primary } \\
\text { treatment) }\end{array}$ & $\begin{array}{l}\text { Follow up after } \\
\text { last treatment } \\
\text { (months) }\end{array}$ \\
\hline 1 & $\begin{array}{l}\mathrm{R} \\
\mathrm{L}\end{array}$ & 4 months & $\begin{array}{l}\text { III } \\
\text { IV, TRD }\end{array}$ & $\begin{array}{l}\text { complete fragmentation } \\
\text { complete fragmentation } \\
\text { complete reapplication }\end{array}$ & $\begin{array}{l}\text { thermochemotherapy } \\
{ }_{125} \mathrm{I} \\
\text { thermochemotherapy } \\
\text { cryotherapy }\end{array}$ & cf Table 2 & \\
\hline 2 & $\begin{array}{l}\mathrm{R} \\
\mathrm{L}\end{array}$ & 3 months & $\begin{array}{l}\text { III } \\
\text { V, buphthalmia }\end{array}$ & $\begin{array}{l}\text { partial fragmentation } \\
\text { ocular atrophy }\end{array}$ & $\begin{array}{l}\text { thermochemotherapy } \\
\text { enucleation }\end{array}$ & cf Table 2 & \\
\hline 3 & $\begin{array}{l}\mathrm{R} \\
\mathrm{L}\end{array}$ & 23 days & $\begin{array}{l}\text { III } \\
\text { V }\end{array}$ & $\begin{array}{l}\text { complete fragmentation } \\
\mathrm{NE}\end{array}$ & thermochemotherapy & cf Table 2 & \\
\hline 4 & $\mathrm{R}$ & 6 months & $\mathrm{V}$ & $\begin{array}{l}\text { complete fragmentation } \\
2 \text { new tumours } \\
\text { complete fragmentation }\end{array}$ & thermochemotherapy & cf Table 2 & \\
\hline 5 & $\begin{array}{l}\mathrm{R} \\
\mathrm{L}\end{array}$ & 16 months & $\begin{array}{l}\text { I } \\
\text { III }\end{array}$ & $\begin{array}{l}\text { partial fragmentation } \\
\text { complete fragmentation }\end{array}$ & $\begin{array}{l}\text { thermochemotherapy } \\
\text { EBR }\end{array}$ & cf Table 2 & \\
\hline 6 & $\begin{array}{l}\mathrm{R} \\
\mathrm{L}\end{array}$ & 18 months & $\begin{array}{l}\text { V, TRD } \\
\text { III }\end{array}$ & $\begin{array}{l}\text { partial fragmentation, TRD } \\
\text { partial fragmentation }\end{array}$ & $\begin{array}{l}\text { enucleation } \\
\text { thermochemotherapy }\end{array}$ & cf Table 2 & \\
\hline 7 & $\mathrm{R}$ & 15 months & $\mathrm{V}$, vitreous seeding, TRD & $\begin{array}{l}\text { complete fragmentation } \\
\text { stable vitreous seeding } \\
\text { complete reapplication }\end{array}$ & EBR & 8 months (enucleation) & 10 \\
\hline 8 & $\begin{array}{l}\mathrm{L} \\
\mathrm{R}\end{array}$ & 10 months & $\begin{array}{l}\text { V, vitreous seeding, TRD } \\
\text { V }\end{array}$ & $\begin{array}{l}\text { id } \\
\text { partial fragmentation } \\
\text { TRD }\end{array}$ & $\begin{array}{l}\text { EBR } \\
\text { enucleation }\end{array}$ & & 18 \\
\hline & $\mathrm{L}$ & & III & partial fragmentation & EBR & & 31 \\
\hline 9 & $\begin{array}{l}\mathrm{R} \\
\mathrm{L}\end{array}$ & 3 months & $\begin{array}{l}\text { III } \\
\text { V }\end{array}$ & $\begin{array}{l}\text { partial fragmentation }+3 \text { new tumors } \\
\text { NE }\end{array}$ & EBR & & 29 \\
\hline 10 & $\begin{array}{l}\mathrm{R} \\
\mathrm{L}\end{array}$ & 14 months & $\begin{array}{l}\text { V, TRD } \\
\text { V, vitreous seeding }+++\end{array}$ & $\begin{array}{l}\text { TRD } \\
\text { partial fragmentation } \\
\text { reduction of vitreous seeding }\end{array}$ & $\begin{array}{l}\text { enucleation } \\
\text { EBR }\end{array}$ & & 24 \\
\hline 11 & $\begin{array}{l}\mathrm{R} \\
\mathrm{L}\end{array}$ & 15 months & $\begin{array}{l}\text { III } \\
\text { III }\end{array}$ & $\begin{array}{l}\text { partial fragmentation } \\
\text { complete fragmentation }\end{array}$ & $\begin{array}{l}\text { EBR } \\
\text { EBR }\end{array}$ & & $\begin{array}{l}20 \\
20\end{array}$ \\
\hline 12 & $\begin{array}{l}\mathrm{R} \\
\mathrm{L}\end{array}$ & 24 days & $\begin{array}{l}\text { V, TRD } \\
\text { V, TRD }\end{array}$ & $\begin{array}{l}\text { partial fragmentation, TRD } \\
\text { partial fragmentation } \\
\text { TRD }\end{array}$ & $\begin{array}{l}\text { EBR } \\
\text { EBR }\end{array}$ & $\begin{array}{l}6 \text { months (secondary enucleation) } \\
\text { (secondary enucleation) }\end{array}$ & 6 \\
\hline 13 & $\begin{array}{l}\mathrm{R} \\
\mathrm{L}\end{array}$ & 4 months & $\begin{array}{l}\text { I } \\
\text { V }\end{array}$ & $\begin{array}{l}\text { partial fragmentation } \\
\text { NE }\end{array}$ & abstention & 4 months EBR & 18 \\
\hline 14 & $\mathrm{R}$ & 14 months & $\begin{array}{l}\text { V, vitreous seeding } \\
\text { TRD }\end{array}$ & $\begin{array}{l}\text { total fragmentation, stable vitreous } \\
\text { seeding } \\
\text { retinal reapplication }\end{array}$ & EBR & & 23 \\
\hline & $\mathrm{L}$ & & $\begin{array}{l}\mathrm{V} \\
\text { TRD, vitreous seeding? }\end{array}$ & $\begin{array}{l}\text { partial fragmentation } \\
\text { TRD, vitreous stable }\end{array}$ & enucleation & & \\
\hline 15 & $\begin{array}{l}\mathrm{R} \\
\mathrm{L}\end{array}$ & 9 months & $\begin{array}{l}\text { III } \\
\text { III }\end{array}$ & $\begin{array}{l}\text { partial fragmentation } \\
\text { partial fragmentation } \\
\text { vitreous progression }\end{array}$ & $\begin{array}{l}\text { EBR } \\
\text { EBR }\end{array}$ & & $\begin{array}{l}18 \\
18\end{array}$ \\
\hline 16 & $\mathrm{R}$ & 4 months & TH & partial fragmentation & EBR & $\begin{array}{l}22 \text { months } \\
\text { (thermochemotherapy) }\end{array}$ & 5 \\
\hline & $\mathrm{L}$ & & IV, partial RD & $\begin{array}{l}\text { complete fragmentation, complete } \\
\text { reapplication }\end{array}$ & EBR & & 27 \\
\hline 17 & $\mathrm{R}$ & 3 months & V, TRD & $\begin{array}{l}\text { complete fragmentation } \\
\text { complete reapplication } \\
\text { progr vitreous }\end{array}$ & EBR & & 18 \\
\hline & $\mathrm{L}$ & & $\begin{array}{l}\mathrm{V} \\
\text { partial RD }\end{array}$ & $\begin{array}{l}\text { complete fragmentation } \\
\text { complete reapplication } \\
\text { progr vitreous }\end{array}$ & EBR & & 18 \\
\hline 18 & $\begin{array}{l}\mathrm{R} \\
\mathrm{L}\end{array}$ & 24 months & $\begin{array}{l}\mathrm{V} \\
\mathrm{V}(\text { large } \mathrm{T}) \\
\text { vitreous }+\end{array}$ & $\begin{array}{l}\mathrm{NE} \\
\text { partial fragmentation } \\
\text { reduction of vitreous seeding }\end{array}$ & EBR & 8 months (cryotherapy) & 1 (lost FFU) \\
\hline 19 & $\mathrm{R}$ & 8 months & vitreous seeding, TRD V+ & $\begin{array}{l}\text { partial fragmentation } \\
\text { TRD }\end{array}$ & enucleation & & \\
\hline & $\mathrm{L}$ & & $\begin{array}{l}\mathrm{V} \\
\text { vitreous seeding } \\
\text { TRD }\end{array}$ & $\begin{array}{l}\text { partial fragmentation } \\
\text { stable vitreous seeding } \\
\text { partial retinal reapplication }\end{array}$ & EBR & & 24 \\
\hline 20 & $\mathrm{R}$ & 13 months & V, TRD & $\begin{array}{l}\text { partial fragmentation } \\
\text { partial fragmentation } \\
\text { NE }\end{array}$ & EBR & 7 months (secondary enucleation) & 13 \\
\hline 21 & $\mathrm{R}$ & 5 months & $\begin{array}{l}\text { IV } \\
\text { partial RD }\end{array}$ & $\begin{array}{l}\text { partial fragmentation } \\
\text { complete retinal reapplication }\end{array}$ & thermochemotherapy & cf Table 2 & \\
\hline 22 & $\mathrm{~L}$ & 8 months & II & partial fragmentation & thermochemotherapy & cf Table 2 & \\
\hline 23 & $\mathrm{~L}$ & 54 months & $\mathrm{V}$ & progressive disease in vitreous & $\begin{array}{l}\text { enucleation and } \\
\text { chemotherapy }\end{array}$ & & 24 \\
\hline
\end{tabular}

$\mathrm{NE}=$ not evaluable (primary enuclation); $\mathrm{TRD}=$ total retinal detachment; $\mathrm{EBR}=$ external beam radiotherapy.

etoposide and carboplatin and thermochemotherapy in patients with intraocular retinoblastoma.

\section{Patients and methods}

NEOADJUVANT CHEMOTHERAPY

Twenty three patients suffering from intraocular retinoblastoma not completely treatable by ophthalmological methods were included in this study between June 1994 and October 1995. Four eligible patients were not included over the same period-two because of predictable poor compliance with follow up and two because of infectious diseases at the time of diagnosis (congenital toxoplasmosis, viral infection).

There were 16 boys and seven girls, aged 24 days to 54 months (median 9 months) presenting with bilateral retinoblastoma in 20 cases and unilateral retinoblastoma in three cases.

Five patients with bilateral retinoblastoma underwent immediate unilateral enucleation. Thirty eight eyes were therefore evaluable for efficacy, corresponding to Reese groups I (two), II (one), III (12), IV (3), and V (20). All 
Table 2 Thermochemotherapy

\begin{tabular}{|c|c|c|c|c|c|c|c|c|c|}
\hline \multicolumn{2}{|c|}{ Patient No } & \multirow{2}{*}{$\begin{array}{l}\text { Age of } \\
\text { diagnosis } \\
\text { (months) } \\
\star\end{array}$} & \multirow{2}{*}{$\begin{array}{l}\begin{array}{l}\text { Previous } \\
\text { treatment }\end{array} \\
\text { Neoadj chemo }\end{array}$} & $\begin{array}{l}\text { Other local } \\
\text { treatment } \\
\text { (of other tumours } \\
\text { of the same eye) }\end{array}$ & \multirow{2}{*}{$\begin{array}{l}\text { Thermochemotherapy } \\
\text { cycles } \\
1+\text { cryo }\end{array}$} & \multirow[t]{2}{*}{$\begin{array}{l}\text { Time to } \\
\text { recurrence } \\
\text { (months) }\end{array}$} & \multirow{2}{*}{$\begin{array}{l}\text { Ocular outcome } \\
\text { Tumour inert }\end{array}$} & \multirow[t]{2}{*}{ Treatment of recurrence } & \multirow{2}{*}{ 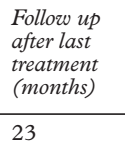 } \\
\hline 1 & T1 R & & & Cryo & & & & & \\
\hline & T2 R & $\star$ & Neoadj chemo & Cryo & 3 & & Tumour inert & & 21 \\
\hline \multirow[t]{2}{*}{2} & $\mathrm{~T} 1 \mathrm{R}$ & $\star$ & Neoadj chemo & ${ }^{125} \mathrm{I}$ & 3 & & Tumour inert & & 19 \\
\hline & $\mathrm{T} 2 \mathrm{R}$ & $\star$ & Neoadj chemo & ${ }^{125} \mathrm{I}$ & 3 & & Tumour inert & & 19 \\
\hline 3 & $\mathrm{R}$ & $\star$ & Neoadj chemo & Cryo & 3 & 5 & Recurrence & Ext beam irr & 19 \\
\hline \multirow[t]{2}{*}{4} & $\mathrm{R}$ & $\star$ & Neoadj chemo & Cryo & 3 & 2 & Recurrence & Ext beam irr & 19 \\
\hline & $\mathrm{L}$ & $\star$ & Neoadj chemo & & 3 & 6 & Recurrence & 2 cryo + Thermochemo & 12 \\
\hline 5 & $\mathrm{~L}$ & $\star$ & Neoadj chemo & & 3 & & Tumour inert & & 14 \\
\hline 6 & $\mathrm{R}$ & $\star$ & Neoadj chemo & Cryo & 3 & 3 & Recurrence & Thermochemo + Cryo $+{ }^{125} \mathrm{I}$ & 4 \\
\hline 21 & $\mathrm{~L}$ & $\star$ & Neoadj chemo & & 3 & 2 & Recurrence & Cryo $+{ }^{125} \mathrm{I}+$ Thermochemo & 14 \\
\hline 22 & $\mathrm{~L}$ & $\star$ & Neoadj chemo & & 3 & 24 & Recurrence & 3 Cryo & 6 \\
\hline 24 & $\begin{array}{l}\mathrm{L} \\
\mathrm{R}\end{array}$ & 3 & Neoadj chemo & $\begin{array}{l}\text { Cryo } \\
\text { Cryo }+{ }^{125} \mathrm{I}\end{array}$ & 3 & 3 & Recurrence & ${ }^{125} \mathrm{I}$ & 29 \\
\hline \multirow[t]{2}{*}{25} & $\mathrm{~L}$ & 5 & & Cryo & 3 & & Tumour inert & & 32 \\
\hline & $\mathrm{R}$ & & Directly & Enucleation & & & & & Enucleation \\
\hline 26 & $\begin{array}{l}\mathrm{R} \\
\mathrm{L}\end{array}$ & 4 & $\begin{array}{l}\text { Cryo } \\
\text { Directly }\end{array}$ & $\begin{array}{l}\text { Cryo }+{ }^{125} \mathrm{I} \\
\text { Enucleation }\end{array}$ & 2 & 5 & Recurrence & Thermochemo & 18 \\
\hline 27 & $\begin{array}{l}\mathrm{R} \\
\mathrm{L}\end{array}$ & 9 & $\begin{array}{l}\text { Cryo } \\
\text { Directly }\end{array}$ & $\begin{array}{l}\text { Cryo } \\
\text { Enucleation }\end{array}$ & $1+$ Cryo & & Tumour inert & & 20 \\
\hline \multirow[t]{2}{*}{28} & $\mathrm{~L}$ & 6 & Cryo & Cryo & $1+$ Cryo & & Tumour inert & & 13 \\
\hline & $\mathrm{R}$ & & Cryo + thermo & chemo (not includ & ed in the study) & & & & \\
\hline \multirow[t]{4}{*}{29} & $\mathrm{~T} 1 \mathrm{R}$ & & Cryo & Cryo & 3 & 7 & Recurrence & & 4 \\
\hline & $\mathrm{T} 2$ & & Cryo & Cryo & 3 & & Tumour inert & Ext beam irr & 4 \\
\hline & $\mathrm{T} 1 \mathrm{~L}$ & 1 & Laser alone & Cryo $+{ }^{125} \mathrm{I}$ & 3 & & Tumour inert & & 16 \\
\hline & $\mathrm{T} 2$ & & Laser alone & Cryo $+{ }^{125} \mathrm{I}$ & 3 & & Tumour inert & & 16 \\
\hline 30 & $\mathrm{~L}$ & 9 & & & 3 & & Tumour inert & & 24 \\
\hline
\end{tabular}

group $\mathrm{V}$ cases corresponded to large tumours (Va) and not only localised vitreous seeding (Vb).

Chemotherapy consisted of etoposide at the dose of $150 \mathrm{mg} / \mathrm{m}^{2} /$ day from day 1 to day 3 by 1 hour infusions and carboplatin at the dose of $200 \mathrm{mg} / \mathrm{m}^{2} /$ day from day 1 to day 3 by 1 hour infusions; the doses were adapted to weight ( 5 $\mathrm{mg} / \mathrm{kg} /$ day and $6.7 \mathrm{mg} / \mathrm{kg} /$ day respectively) in bodies weighing less than $10 \mathrm{~kg}$ and under the age of 1 year. The treatment plan consisted of administration of two successive courses, separated by an interval of 21 days, with ocular fundus examination after both courses. Haematological follow up consisted of at least two blood cell counts per week, or more frequently depending on the clinical context. Patients received prophylactic treatment with sulphamethoxazole-trimethoprim and platelet transfusion recommendations were designed to maintain the platelet count above $50 \times 10^{6} / 1$ in order to limit the risk of intraocular haemorrhage.

\section{THERMOCHEMOTHERAPY}

Between January and October 1995, we treated 21 tumours in 17 eyes of 15 children with the combination of carboplatin and diode laser. ${ }^{20}$ Retinoblastoma was unilateral in two cases, and bilateral in 13 cases; there were nine boys and six girls aged 1-23 months (median 6 months). The tumour diameter was between 1.5 and $10 \mathrm{~mm}$ (median $4.5 \mathrm{~mm}$ ).

In eight cases, treatment was performed after reduction of tumour volume by two courses of etoposide and carboplatin. In all but one case the tumour was located at the posterior pole close to, but not invading, the macula in five cases, and close to the optic disc in three cases. In three cases, treatment was delivered for focal relapse after cryotherapy, and in one case treatment was delivered for recurrence after treatment with carboplatin and crystal laser.
Other local treatments for other tumour sites on the same eye were simultaneously associated in 11 eyes: cryotherapy and ${ }^{125} \mathrm{I}$ at the retinal periphery, xenon arc photocoagulation at the posterior pole.

In one case, we treated a 5 day old baby with diode laser alone and started carboplatin associated with diode laser at 1 month for two lesions very close to the macula.

The 1 hour intravenous infusion of carboplatin was administered at the dose of $18 \mathrm{mg} / \mathrm{kg}$, while the child was in the paediatric department. Two hours after the infusion, the child was taken to the operating room for general deep anaesthesia after complete pupillary dilatation. The tumour was treated with diode laser $(810 \mathrm{~nm}$ now marketed by Iris Medical Inc) for 20 minutes by continuous mode. At day 8 , a new laser treatment, not preceded by carboplatin infusion, was performed under general anaesthesia. At day 28, a new course was performed with a total of three cycles (three intravenous infusions of carboplatin and six laser treatments). We used a spot of $1.2 \mathrm{~mm}$ and $600 \mathrm{~mW}$ in nine tumours, $0.8 \mathrm{~mm}$ and 300 $\mathrm{mW}$ in six tumours, and $0.3 \mathrm{~mm}$ and $150 \mathrm{~mW}$ in four tumours.

In three cases, the tumour was totally flattened after one cycle, but as a safety measure, we preferred complete treatment by cryotherapy.

\section{Results}

NEOADJUVANT CHEMOTHERAPY

Efficacy after two courses

Detailed outcome of the eyes, according to the Reese groupings, is shown in Tables 1 and 2. In large bilateral tumours, examination after neoadjuvant chemotherapy determined the need for enucleation, specifically when total retinal detachment persisted. Seven eyes were enucleated after chemotherapy and none of them presented any histological risk factor. Two of 


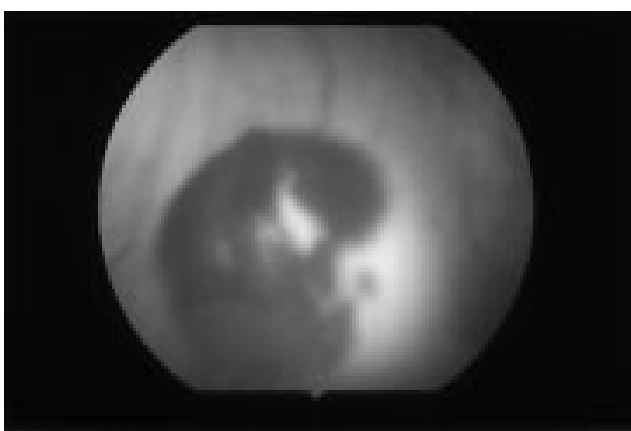

Figure 1 Patient 5. Clinical aspect of one of the tumours immediately after the first diode laser treatment.

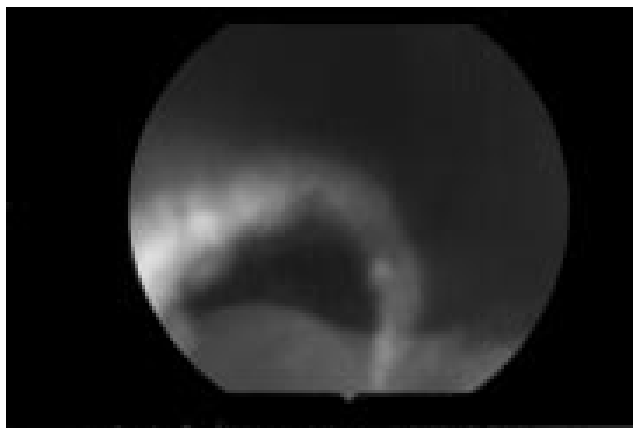

Figure 2 Patient 5. Clinical aspect of the final scar after three years of thermochemotherapy.

three patients with unilateral retinoblastoma were suitable for a conservative approach avoiding external beam radiotherapy with a follow up of 6 and 14 months after the last treatment, and five eyes of six patients with bilateral retinoblastoma were suitable for a conservative approach avoiding external beam radiotherapy with a median follow up of 14 months. However, radiation therapy could not be avoided in all cases, especially in Reese group $\mathrm{V}$ eyes with large tumours.

Toxicity

Forty five courses were evaluable for toxicity. Grade IV neutropenia with a median duration of 10 days was observed in 31 courses. Admission to hospital for infectious problems was necessary in 10 courses delivered to nine patients - fever of undetermined origin during neutropenia after five courses (median hospital stay 5 days), septicaemia without neutropenia in children with central venous catheter after four courses (Staphylococcus aureus, Candida albicans, and Pseudomonas), and viral gastroenteritis after one course. No haemoglobin level was under $65 \mathrm{~g} / 1$; red blood cell transfusion was necessary after nine courses in eight patients. Platelet transfusions were necessary after three courses in two patients.

\section{THERMOCHEMOTHERAPY}

Efficacy

Detailed outcome of the eyes is reported in Table 2.

Figures 1 and 2 show the tumour of patient 5 immediately after and at the end of treatment.

No relapse of tumours treated by three cycles of thermochemotherapy occurred in nine tumours (seven eyes of six patients) with a median follow up of 19.2 months (range 12-32). No relapse also occurred in three tumours (three eyes of three patients) treated by one cycle of thermochemotherapy and completed by cryotherapy with a follow up of 13.2, 20, and 23 months. Local relapse occurred in nine tumours (nine eyes of eight patients). Treatment of relapses consisted of thermochemotherapy alone in one eye, cryotherapy alone in one eye, radioactive iodine plaque alone in one eye, thermochemotherapy and cryotherapy in one eye, thermochemotherapy and radioactive iodine plaque on the peripheral part of the tumour in two eyes, and external ocular irradiation in three eyes.

The median follow up after treatment of eyes with local relapse was 13.8 months (range 4-29). To date, external irradiation has been avoided in 14 of the 17 eyes.

\section{Toxicity}

Forty seven courses were evaluable for toxicity; grade IV neutropenia was observed in 21 courses in nine patients with a median duration of 5 days. Hospitalisation for febrile neutropenia was required in five courses in four patients with a duration of 4-10 days. Other infections occurred despite the absence of neutropenia and required hospitalisationthree cases of septicaemia in children with central venous catheters ( $S$ aureus and Enterobacter). Platelet transfusions were necessary in six courses for five patients and erythrocyte transfusion was necessary in one course.

We have observed one case of papillopathy resembling central retinal vein occlusion in one child after treatment of a juxtapapillary tumour with a $1.2 \mathrm{~mm}$ spot. This papillopathy was associated with localised serous detachment. We also observed two cases of iridial lesions with no visual disorders in children whose pupils were probably insufficiently dilated during laser treatment.

In our series, ocular fundus examination did not reveal any particular retinal toxicity after this treatment sequence including chemotherapy.

\section{Discussion}

NEOADJUVANT CHEMOTHERAPY

A response to chemotherapy in terms of tumour fragmentation is generally observed in the treatment of intraocular retinoblastoma by etoposide and carboplatin. ${ }^{16}$ The main site of treatment failure is the vitreous, ${ }^{21}$ although tumour responses have also been reported in cases of vitreous invasion present at the time of diagnosis. The immediate toxicity of this treatment is acceptable and its management corresponds to the usual context of management of chemotherapy complications in young children. However, this toxicity is not negligible and the indications for chemotherapy in the treatment of intraocular retinoblastoma must be considered in terms of the expected therapeutic benefit.

There is a definite therapeutic benefit when external irradiation can be avoided. ${ }^{16} \mathrm{~A}$ trial of neoadjuvant chemotherapy is therefore justified when the initial tumour presentation suggests that, after reduction by chemotherapy, 
the lesions will become accessible to conservative local treatments other than external irradiation (cryotherapy, iodine plaque, thermochemotherapy, photocoagulation).

The benefit of chemotherapy is less clear in the context of large bilateral tumours. ${ }^{15}$ The objective is to try to improve the visual prognosis by releasing a healthy area of retina or even the macula by means of the initial tumour response. In these cases, conservative treatment can only consist of bilateral external irradiation or unilateral irradiation with contralateral enucleation, except in the experience reported by Gallie, ${ }^{16}$ using cyclosporin in combination with chemotherapy.

\section{THERMOCHEMOTHERAPY}

Thermochemotherapy requires optimal collaboration between paediatricians, anaesthesiologists, and ophthalmologists. ${ }^{20}$ A central venous catheter is often necessary. Pupillary dilatation must be complete because the diode laser must not touch the iris during treatment. The choice of the spot diameter and energy has to be adapted to each tumour. Underdosage carries a risk of tumour recurrence. Overdosage carries a risk of damage to macula or optic disc.

We consider that, even when the tumour is totally flattened and replaced by pigment disturbance after one cycle, the treatment was probably too light; so as a safety measure, we preferred to complete treatment by cryotherapy when possible.

Based on our experience, it seems preferable to use a $1.2 \mathrm{~mm}$ spot with an energy of 600 $\mathrm{mW}$, if this treatment only induces whitening of the tumour with small haemorrhage. If the treatment induces wide oedema around the lesion, the hyperthermia is probably too intense and a smaller spot size and energy should be used, especially when treating lesions close to the macula or optic disc.

Despite its efficacy, we report a significant number of local relapses after thermochemotherapy. Most of these relapses can be explained by an insufficient therapeutic protocol; only two cycles in two cases, only one spot for a very large tumour (more than $6 \mathrm{~mm}$ in diameter) in three cases.

This risk of local relapse is often observed after other types of conservative ophthalmological treatments which may need to be repeated. However, according to Murphree and colleagues' results, ${ }^{21}$ local relapses are usually accessible to ophthalmological treatments avoiding external irradiation.

As this is a recent treatment with a short follow up, the children are carefully followed with examination of the fundus under general anaesthesia every month for at least 1 year.

\section{Conclusions}

Intraocular retinoblastoma, like extraocular lesions, is sensitive to chemotherapy with etoposide and carboplatin. ${ }^{16}$ There is a definite therapeutic benefit when this treatment makes the tumour accessible to conservative treatment other than external irradiation. In the other cases, the benefit must be demonstrated by subsequent randomised prospective trials.
The combination of carboplatin chemotherapy and hyperthermia with diode laser seems to be an advance in the treatment of retinoblastoma. It should represent a new therapeutic approach, avoiding the need for external beam radiation in small to moderately large posterior pole lesions..$^{22}$ Nevertheless, the results presented here are preliminary and need to be re-evaluated with a longer follow up.

The therapeutic benefit of chemotherapy must also be demonstrated, in particular, in bilateral or multifocal unilateral forms, as these drugs might increase the risk of secondary sarcoma, even when external irradiation has been avoided.

We thank Drs Daltroff, Rialland, Méchinaud, Lefur, Fagnou, and Marguerite, for their help in the follow up of patients under chemotherapy.

1 Donaldson S, Egbert PR, Newsham I, et al. Retinoblastoma. In: Pizzo PA, Poplack DG, eds. Principles and practice of pediatric oncology. 3rd ed. Philadelphia: JB Lippincott, 1997:699-715.

2 Buckley EG, Heath $H$. Visual acuity after successful reatment of large macular retinoblastoma. $\mathcal{F}$ Pediatr Ophthalmol Strabismus 1992;29:103-6.

3 Hawkins M, Kinnier Wilson LM, Burton HS, et al. Radiotherapy, alkylating agents, and risk of bone cancer after childhood cancer. $\mathcal{F}$ Natl Cancer Inst 1996;88:270-7.

4 Shields CL, Shields JA. Intraocular tumors: a text and atlas. Philadelphia: WB Saunders, 1992:305-91.

5 Fontanesi J, Pratt CB, Tlustu HO, et al. Use of irradiation for therapy of retinoblastoma in children more than 1 year: the St Jude Children's Research Hospital experience and review of literature. Medical and Pediatric 1995;25:321-6.

6 Haye C, Desjardins L, Schlienger P, et al. Treatment of bilateral retinoblastoma stage $\mathrm{V}$ at the Curie Foundation: 33 cases. Ophthalmic Paediatr Genet 1987;8:73-6.

7 Weiss AH, Karr DJ, Kalina RE, et al. Visual outcomes of Weiss AH, Karr DJ, Kalina RE, et al. Visual outcomes of
macular retinoblastoma after external beam radiation macular retinoblastoma after external

8 Pomarede R, Czernichow P, Zucker JM, et al. Incidence of anterior pituitary deficiency after radiotherapy at an early age: study in retinoblastoma. Acta Peadiatr Scand 1984;73: 115-19.

9 Desjardins L, Haye C, Schlienger P, et al. Second non-ocular tumors in survivors of bilateral retinoblastoma. A 30 year follow up. Ophthalmic Paediatr Genet 1991;12:145-8.

10 Eng C, Li F, Abramson DH, et al. Mortality from second tumors among long term survivors of retinoblastoma. $f$ Natl Cancer Inst 1993;85:1121-8.

11 Doz F, Khelfaoui F, Mosseri V, et al. The role of chemotherapy in orbital involvement of retinoblastoma. The experience of a single institution with 33 patients. Cancer 1994;74:722-32.

12 Doz F, Neuenschwander S, Plantaz D, et al. Etoposide and carboplatin in extraocular retinoblastoma: a study by the Société Française d'Oncologie Pédiatrique. 7 Clin Oncol 1995;13:902-9.

13 Doz F, Pinkerton R. What is the place of carboplatin in paediatric oncology? Eur $\mathcal{F}$ Cancer 1994;30A: 194-201

4 Kingston JE, Hungerford JL, Madreperla SA, et al. Results of combined chemotherapy and radiotherapy for advanced intraocular retinoblastoma. Arch Ophthalmol 1996;114: 1336-43.

15 Shields CL, De Potter P, Himelstein BP, et al. Chemoreduction in the initial management of intraocular retinoblastoma. Arch Ophthalmol 1996;114:1330-8.

16 Gallie B, Budning A, De Boer G, et al. Chemotherapy with focal therapy can cure intraocular retinoblastoma without radiotherapy. Arch Ophthalmol 1996;114:1321-8.

17 Freire J, Miyamoto C, Brady LW, et al. Retinoblastoma after chemoreduction and irradiation: preliminary results. Rachemoreduction and irradiation: preliminary results. Radiotherapy of ocular disease.

18 Hanh G, Shiu EC. Effect of $\mathrm{pH}$ and elevated temperatures on the cytotoxicity of some therapeutic agents on Chinese hamster cells in vitro. Cancer Res 1983;43:5789-91

$19 \mathrm{Xu} \mathrm{MJ}$, Alberts DS. Potentiation of platinum analogue cytotoxicity by hyperthermia. Cancer Chemother Pharmacol 1988;21:191-6.

20 Murphree AL, Stout AU, Szirth B, et al. Carboplatin and laser generated hyperthermia: preliminary results in the treatment of focal intraocular retinoblastoma. Invest Ophthalmol Vis Sci 1992;33:877 (abstract)

21 Murphree AL, Steele D, Matagolowkin M, et al. Thermochemotherapy for retinoblastoma: protocol, instrumentation and outcome. International Society for Genetic Eye Disease Symposia, 24 June 1994

22 Murphree AL, Villablanca JG, Deegan WF, et al. Chemotherapy plus local treatment in the management of therapy plus local treatment in the management of
intraocular retinoblastoma. Arch Ophthalmol 1996;114: intraocular. 